\title{
The role of thymidine phosphorylase in the induction of early growth response protein-1 and thrombospondin-1 by 5-fluorouracil in human cancer carcinoma cells
}

\author{
SHIGETO MATSUSHITA ${ }^{1,2^{*}}$, RYUJI IKEDA $^{3 *}$, YUKIHIKO NISHIZAWA ${ }^{3}$, XIAO-FANG CHE ${ }^{1}$, \\ TATSUHIKO FURUKAWA ${ }^{1}$, KAZUTAKA MIYADERA ${ }^{4}$, SHO TABATA ${ }^{3}$, MINA USHIYAMA ${ }^{3}$, YUSUKE TAJITSU ${ }^{3}$, \\ MASATATSU YAMAMOTO ${ }^{1}$, YASUO TAKEDA ${ }^{3}$, KENTARO MINAMI ${ }^{3}$, HIRONORI MATAKI ${ }^{3}$, \\ TAMOTSU KANZAKI ${ }^{2}$, KATSUSHI YAMADA ${ }^{3}$, TAKURO KANEKURA ${ }^{2}$ and SHIN-ICHI AKIYAMA ${ }^{1}$ \\ ${ }^{1}$ Department of Molecular Oncology, ${ }^{2}$ Department of Dermatology, Field of Sensory Organology, ${ }^{3}$ Clinical Pharmacy \\ and Pharmacology, Graduate School of Medical and Dental Sciences, Kagoshima University, Sakuragaoka 8-35-1, \\ Kagoshima 890-8520; ${ }^{4}$ Taiho Pharmaceutical Co. Ltd., Misugidai 1-27 Hanno 357, Japan
}

Received October 19, 2009; Accepted December 18, 2009

DOI: 10.3892/ijo_00000602

\begin{abstract}
Thymidine phosphorylase (TP) is an enzyme involved in reversible conversion of thymidine to thymine. $\mathrm{TP}$ is identical to an angiogenic factor, pletelet-derived endothelial cell growth factor (PD-ECGF) and the expression levels of TP in a variety of malignant tumors were higher than the adjacent non-neoplastic tissues. To investigate the molecular basis for the effect of TP on the metabolic process and the anticancer effect of 5-fluorouracil (5-FU), human gastric carcinoma AZ521 cells and epidermoid carcinoma KB cells were transfected with TP cDNA, and AZ521/TP and KB/ TP were cloned. AZ521/TP and KB/TP cells overexpressed $\mathrm{TP}$ and were more sensitive to 5-FU than the counterpart parental cells. TPI, a newly synthesized inhibitor for TP $\left(\mathrm{Ki}=2.36 \times 10^{-9} \mathrm{M}\right)$, decreased the sensitivity to $5-\mathrm{FU}$ of the TP expressing cells but not of the parental cells. 5-Formyl-
\end{abstract}

Correspondence to: Dr Shin-ichi Akiyama, Department of Molecular Oncology, Graduate School of Medical and Dental Sciences, Kagoshima University, Sakuragaoka 8-35-1, Kagoshima 890-8520, Japan

E-mail: akiyamas@m3.kufm.kagoshima-u.ac.jp

*Contributed equally

Abbreviations: TP, thymidine phosphorylase; PD-ECGF, plateletderived endothelial cell growth factor; 5-FU, 5-fluorouracil; TPI, thymidine phosphorylase inhibitor; LV, leucovorin; PBS, phosphatebuffered saline; DAB, diaminobenzidine; TS, thymidylate synthetase; FdUMP, 5-fluoro-deoxyuridine-monophosphate; MTT, 3-(4,5Dimethylthiazol-2-yl)-2,5-diphenyltetrazolium bromide; HPLC, high performance liquid chromatography; PARP, poly (ADP-ribose) polymerase; TSP-1, thrombospondin-1; Egr-1, early growth response protein-1; aPAI-1, plasminogen activator inhibitor; 5'-DFUR, 5'-deoxy-5-fluorouridine

Key words: thymidine phosphorylase, 5-fluorouracil, leucovorin, FdUMP, thymidylate synthase, ternary complex, TSP-1 tetrahydrofolate (leucovorin; LV) stabilized the complex of thymidylate synthase (TS) and 5-fluoro-deoxyuridinemonophosphate (FdUMP), increased the sensitivity to 5-FU of TP expressing AZ521 cells, but not of the parental cells. The levels of FdUMP in TP expressing cells were significantly higher than in parental cells and TPI considerably decreased FdUMP to the level comparable to that in the parental cells. 5-FU increased the expression of early growth response protein-1 (Egr-1) and an angiogenesis inhibitor, thrombospondin-1 (TSP-1), in KB/TP cells but only slightly in $\mathrm{KB} / \mathrm{CV}$ cells, if any. TPI attenuated the induction of Egr-1 and $T S P-1$ mRNA by $5-\mathrm{FU}$, while LV increased the expression of Egr- 1 and TSP-1 mRNA in KB/TP cells. These findings demonstrate that the TP has a principal role in the production of FdUMP and the enhanced responses to 5-FU by leucovorin in TP-overexpressing KB and AZ521 cells, and FdUMP but not FUTP is implicated in the induction of Egr-1 and TSP-1 in KB cells.

\section{Introduction}

Thymidine phosphorylase (TP) catalyzes the reversible phosphorolysis of thymidine, deoxyuridine, and their analogues to their respective bases and 2-deoxyribose-1phosphate (1-3). It also catalyzes deoxyribosyltransfer from one deoxynucleotide to another base, to form a second deoxyuridine (4-6). Recent studies showed that TP is expressed in a wide variety of solid tumors (7-13), but the role of TP in tumor proliferation was unknown. We have found that TP is identical to an angiogenic factor, platelet-derived endothelial cell growth factor (PD-ECGF), and the enzymatic activity of TP is need for the angiogenesis by TP (14-16). TP is also considered to activate some pyrimidine antimetabolites (17-19). 5-Fluorouracil (5-FU) was developed as a potential anti-tumor drug (20), and reportedly activated through three alternative routes. It may be converted to FUMP either directly by orotate phosphoribosyltranferase or by the sequential actions of uridine phosphorylase and uridine kinase. FUMP may be converted to FUDP and then to FUTP, 
which is incorporated into RNA, thus interfering with its synthesis and nuclear processing. Alternatively, FUMP is converted to FUDP by pyrimidine kinase and converted to FdUDP by ribonucleotide reductase. FdUDP is then converted to 5-fluoro-deoxyuridine-monophosphate (FdUMP) which inhibits thymidylate synthetase and hence DNA synthesis. Another route of 5-FU activation to FdUMP is catalyzed by TP and thymidine kinase. Thymidylate synthase (TS) (EC 2.1.1.45), which converts deoxyuridine monophosphate (dUMP) to thymydilate, plays an essential role in the synthesis of DNA. Inhibition of TS by 5-FU is mediated by the formation of a stable ternary complex between the active anabolite FdUMP, the target enzyme TS, and the cofactor 5,10-methylenetetrahydrofolates $\left(5,10-\mathrm{CH}_{2} \mathrm{H}_{4}\right.$ PteGlun $)$ $(21,22)$. Recently, we have indicated that 5 -FU activated p38 MAPK and then upregulated Egr-1 expression, resulting in the expression of an endogenous antiangiogenic factor, TSP-1. The induction of TSP-1 was suggested to be implicated in the antitumor effect 5-FU (23). However, the molecular basis for the induction by $5-\mathrm{FU}$ is not fully understood. In this study, we examined whether TP is needed for the induction of TSP-1 by 5-FU, and which of the two cytotoxic metabolites of 5-FU, FUTP and FdUMP, is involved in the induction of Egr-1 and TSP-1.

\section{Materials and methods}

Chemicals. 5-FU and 3-(4,5-dimethylthiazol-2-yl)-2,5diphenyltetrazolium bromide (MTT) were obtained from Sigma Chemical Co. (St. Louis, MO), leucovorin was from Lederle Co. (Tokyo) and $\left[{ }^{3} \mathrm{H}\right]$ 5-FU $(15.3 \mathrm{mCi} / \mathrm{mmol})$ was from Moravek Biochemicals, Inc. (Brea, CA). TPI, an inhibitor of thymidine phosphorylase and an anti-TS polyclonal antibody were obtained from Taiho Pharmaceutical Co. Ltd. Antibodies against Egr-1, TSP-1 and tubulin were from Santa Cruz Biotechnology and NeoMarker, respectively.

Cell lines. Human gastric carcinoma AZ521 cells, AZ521/ TP, AZ521 cells transfected with PD-ECGF cDNA, human $\mathrm{KB}$ epidermoid carcinoma cells and $\mathrm{KB} / \mathrm{TP}, \mathrm{KB}$ cells transfected with PD-ECGF cDNA, were maintained in minimal essential medium (Life Technologies, Rockville, MD) containing $10 \%$ fetal calf serum. These cells were mycoplasmafree.

Transfection of PD-ECGF cDNA into AZ521 and KB cells. PD-ECGF full length cDNA was kindly provided by Dr K. Miyazono and Dr C.H. Heldin (Ludwig Institute for Cancer Research, Uppsala, Sweden). A KpnI-EcoRI fragment from pPL8 that encompassed the PD-ECGF coding region was cloned between the KpnI and EcoRI restriction sites of pT7T318U (Pharmacia, Uppsala, Sweden). An XbaI-EcoRI fragment from pT7T318U was then cloned between the NheI and EcoRI restriction sites of the expression vector pBKRSV (Stratagene, La Jolla, CA). The expression vector encoding PD-ECGF cDNA (RSV/TP) was transfected into AZ521 and KB cells by electroporation (24). After selection with Geneticin, expression of PD-ECGF/TP in each clone was determined by immunoblotting using an anti-PD-ECGF/ TP monoclonal antibody. TP-positive clones transfected with
RSV/TP (AZ521/TP and KB/TP cells) and TP-negative clones (AZ521 and KB cells) were further analyzed.

Preparation of cell lysate. Cells were lysed in $10 \mathrm{mM}$ Tris- $\mathrm{HCl}$ ( $\mathrm{pH} 7.5$ ) by rapid freeze-thawing in liquid nitrogen. The lysates were centrifuged at $15,000 \mathrm{x}$ g for $20 \mathrm{~min}$ at $4^{\circ} \mathrm{C}$ and the supernatants were resolved by electrophoresis (25). Protein concentrations were determined by the method of Bradford (26).

Immunoblot analysis. The proteins in the supernatants were separated using sodium dodecyl sulfate-polyacrylamide gel electrophoresis (SDS-PAGE) according to the method of Laemmli (27). Proteins in the gel were electrophoretically transferred to a sheet of polyvinylidene difluoride (PVDF) membrane (Immobilon-P transfer membrane; Millipore, Bedford, MA) with Bio-Rad Transblot SD as described (28). The membranes were then reacted with primary antibodies against TP, Egr-1, TSP-1 and poly (ADP-ribose) polymerase (PARP). After incubation, membranes were washed and incubated with anti-mouse or anti-rabbit secondary antibodies. The membranes were developed using the enhanced chemiluminescence Western blotting detection system (Amersham, Buckinghamshire, UK).

Quantitation of drug sensitivity. The sensitivity of parental and transfected cells to agents were determined by 3-(4,5dimethylthiazol-2-yl)-2,5-diphenyltetrazolium bromide (MTT) colorimetric assay as described (29).

Assay of intracellular FdUMP level. Parental and transfected cells were suspended at $2 \times 10^{5}$ cells and incubated with or without $100 \mu \mathrm{M}$ TPI overnight. After a 24-h incubation, cells were exposed to $400 \mathrm{nM}\left[{ }^{3} \mathrm{H}\right] 5-\mathrm{FU}$ for $3 \mathrm{~h}$. Intracellular FdUMP level was analysed by high performance liquid chromatography (HPLC) method as previously descrived (30).

Incorporation of fluoropyrimidines into RNA. Parental and transfected cells were suspended at $5 \times 10^{5}$ cells and incubated with or without $100 \mu \mathrm{M}$ TPI overnight. After a 24-h incubation, cells were exposed to $80 \mathrm{nM}\left[{ }^{3} \mathrm{H}\right] 5-\mathrm{FU}$ for $12 \mathrm{~h}$. Total cellular RNA was isolated and purified with the TRIzol reagent (Life Technologies, Rockville, MD) using phenol/ chloroform followed by isopropanol precipitation as recommended by the manufacturer. The RNA pellet was dissolved with $22 \mathrm{ml}$ TE and quantitated by UV absorbance at 260/280 nm. Radioactivity in an aliquot of the elusion was determined.

RT-PCR methods. Total cellular RNA was extracted using TRIzol reagent according to the manufacturer's instructions (Invitrogen, Carlsbad, CA). RT-PCR was performed with the SuperScript One-Step RT-PCR system and gene-specific primers according to the manufacturer's instructions (Invitrogen). Reaction mixtures containing total RNA (500 ng of each), $0.2 \mathrm{mM}$ dNTPs, $0.2 \mu \mathrm{M}$ of each primer, enzyme mixture including SuperScript II RT, platinum Taq DNA polymerase, and $1 \mathrm{X}$ buffer with $1.2 \mathrm{mM} \mathrm{MgSO}_{4}$ were maintained at $50^{\circ} \mathrm{C}$ for $20 \mathrm{~min}$, then at $94^{\circ} \mathrm{C}$ for $2 \mathrm{~min}$, and PCR was performed as follows: the PCR profile was 30 cycles at $94^{\circ} \mathrm{C}$ for $15 \mathrm{sec}, 55^{\circ} \mathrm{C}$ for $30 \mathrm{sec}$, and $70^{\circ} \mathrm{C}$ for $30 \mathrm{sec}$. The 
Table I. The sensitivity of parental and TP expressing cells to 5-FU without or with TPI, or LV.

\begin{tabular}{lcccc}
\hline & & \multicolumn{2}{c}{ Drug sensitivity $\left[\mathrm{IC}_{50}(\mu \mathrm{M})\right]$} \\
\hline Drugs & KB & KB/TP & AZ521 & AZ521/TP \\
\hline 5-FU & $919.7 \pm 52.35^{\mathrm{a}}$ & $43.0 \pm 18.7^{\mathrm{e}}$ & $9.92 \pm 1.16^{\mathrm{i}}$ & $5.83 \pm 0.38^{\mathrm{m}}$ \\
5-FU + TPI & $1140.0 \pm 115.0^{\mathrm{b}}$ & $848.5 \pm 11.1^{\mathrm{f}}$ & $8.66 \pm 0.79^{\mathrm{j}}$ & $8.84 \pm 0.51^{\mathrm{n}}$ \\
5-FU + LV 1 $\mu \mathrm{M}$ & $1025.3 \pm 102.8^{\mathrm{c}}$ & $8.9 \pm 0.5^{\mathrm{g}}$ & $8.06 \pm 0.44^{\mathrm{k}}$ & $1.00 \pm 0.01^{\mathrm{o}}$ \\
5-FU + LV 10 $\mu \mathrm{M}$ & $979.6 \pm 107.8^{\mathrm{d}}$ & $8.8 \pm 0.4^{\mathrm{h}}$ & $8.57 \pm 0.23^{\mathrm{l}}$ & $1.51 \pm 0.02^{\mathrm{p}}$ \\
\hline
\end{tabular}

The sensitivity of parental and TP expressing cells to 5-FU without or with TPI, or LV was determined by the MTT assay. Each value represents the mean \pm SE of there independent experiments. a vs. e, $\mathrm{P}<0.0001$, a vs. b, a vs. c, a vs. d, N.S., e vs. f, $\mathrm{P}<0.0001, \mathrm{e} v \mathrm{~s}$. g, $\mathrm{P}=0.1414, \mathrm{e} v \mathrm{~s}$. $\mathrm{h}$, $\mathrm{P}=0.1408$, e vs. $\mathrm{f}, \mathrm{P}<0.0001$, e vs. g, e vs h, N.S., i vs. $\mathrm{m}, \mathrm{P}=0.0286$, i vs. j, i vs. $\mathrm{k}$, i vs. 1 , N.S., $\mathrm{m}$ vs $\mathrm{n}, \mathrm{P}=0.0093$, $\mathrm{m}$ vs. $o, P=0.0002$, $\mathrm{m}$ vs. $\mathrm{p}$, $\mathrm{P}=0.0004$.

primers for RT-PCRs were designed based on human sequences in GenBank. These sequences used the following primers: TSP-1, 5'-AGAATGCTGTCCTCGCTGTT-3' (sense), and 5'-TTTCTTGCAGGCTTTGGTCT-3' (antisense); GAPDH, 5'-AGAACATCATCCCTGCCTCTACTGG-3' (sense) and 5'-AAAGGTGGAGGAGTGGGTGTCGCTG-3' (antisense).

Quantitative real-time PCR. The expression levels of TSP-1 mRNA were determined by real-time PCR (PRISM 7900HT, Applied Biosystems) using SYBR Green I (Takara, Ohtsu, Japan) technology following the manufacturer's protocol. The sequence of the primer sets used for this analysis is as follows: These sequences used the following primers: TSP-1, 5'-ATT GATGGAGACGGTATCCTC-3' (sense), 5'-AGGACAG ATGTCATCGATGTC-3' (antisense); GAPDH, 5'-AGAACA TCATCCCTGCCTCTACTGG-3' (sense), 5'-AAAGGTG GAGGAGTGGGTGTCGCTG-3' (antisense).

Caspase 3 activity. Cells were lysed in buffer A [25 mM Hepes (pH 7.4), 5 mM EDTA, 2 mM DTT and $2 \mathrm{mM}$ APMSF, $10 \mu \mathrm{g} / \mathrm{ml}$ pepstatin A and $10 \mu \mathrm{g} / \mathrm{ml}$ leupeptin]. The lysates were clarified by centrifugation and the supernatants were used for enzyme assays. Enzymatic reactions were carried out in buffer A containing $100 \mu \mathrm{g}$ of protein and $50 \mu \mathrm{M}$ Ac-DEVD-AMC as substrates for caspase 3. The reaction mixtures were incubated at $30^{\circ} \mathrm{C}$ for $60 \mathrm{~min}$. Caspase 3 activity was measured at an excitation wavelength of $360 \mathrm{~nm}$ and an emission wavelength of $460 \mathrm{~nm}$ using a FP750 microplate fluorescence reader (Jasco, Tokyo, Japan). The sensitivity of the enzyme assays using AMC as caspase substrates was equivalent to 7-amino-4-methylcoumarin in purified systems.

\section{Results}

Expression level of TP. We examined the expression levels of TP in human gastric carcinoma AZ521 cells, human epidermoid carcinoma KB cells, and the cells transfected with TP (AZ521/TP and KB/TP) by immunoblot analysis using an anti-TP monoclonal antibody. AZ521/TP and KB/TP cells expressed TP, but parent AZ521 and KB cells did not express detectable amount of TP (Fig. 1). AZ521/TP and KB/TP cells

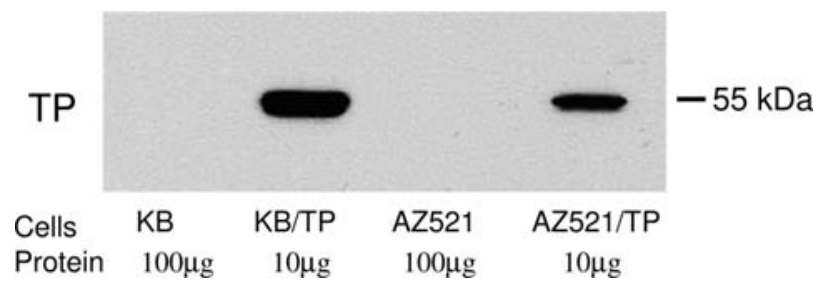

Figure 1. Immunoblot analysis of TP in KB, KB/TP, AZ521 and AZ521/TP cells. Cytosols (10 or $100 \mu \mathrm{g}$ of protein) were separated by SDS-PAGE and transferred to a PVDF membrane. TP levels in the cytosols were determined using a monoclonal antibody against TP.

had high TP activities, but TP activity was not detected in AZ521 and KB cells (data not shown).

Drug sensitivity of parental and TP expressing cell lines. TP is involved in activation of pyrimidine antimetabolites. The sensitivity of parental and TP expressing cells to 5-FU without or with TPI or LV was determined by the MTT assay (Table I). The $\mathrm{IC}_{50}$ values for 5-FU of AZ521 (9.92 \pm 1.16$)$ and KB $(919 \pm 52.35)$ cells were significantly higher than those of AZ521/TP $(5.83 \pm 0.38)$ and KB/TP $(43.0 \pm 18.7)$ cells, respectively and similar to those of AZ521/TP $(8.84 \pm 0.51)$ and KB/TP $(848.5 \pm 11.1)$ cells treated with TPI. Furthermore, the $\mathrm{IC}_{50}$ value $(1.00 \pm 0.01)$ for 5 -FU of $\mathrm{AZ521/TP}$ cells in the presence of $1 \mu \mathrm{M} \mathrm{LV}$ was significantly lower than of AZ521/ TP cells treated with 5 -FU alone. However, the $\mathrm{IC}_{50}$ value (8.9 \pm 0.5$)$ for 5 -FU of $\mathrm{KB} / \mathrm{TP}$ cells in the presence of $1 \mu \mathrm{M} \mathrm{LV}$ was lower than that $(43.0 \pm 18.7)$ of $\mathrm{KB} / \mathrm{TP}$ cells treated with 5-FU alone, but the difference was not significant.

The effect of TP on 5-FU-induced caspase 3 activation. To confirm the cytotoxic activity of 5-FU enhanced by TP, we determined the effect of 5-FU on caspase 3 activity in $\mathrm{KB} / \mathrm{TP}$ and $\mathrm{KB} / \mathrm{CV}$ cells. The caspase 3 activity in $\mathrm{KB} / \mathrm{TP}$ cells treated with $5 \mu \mathrm{M} 5-\mathrm{FU}$ was higher than that in $\mathrm{KB} / \mathrm{CV}$ cells treated with the same concentration of 5-FU (Fig. 2A). We also investigated the cleavage of the caspase 3 substrate $\mathrm{PARP}$ in $\mathrm{KB} / \mathrm{TP}$ and $\mathrm{KB} / \mathrm{CV}$ cells. The cleaved PARP product increased with the increasing concentration of 5-FU up to $20 \mu \mathrm{M}$ in $\mathrm{KB} / \mathrm{TP}$ cells, but only slightly detected in $\mathrm{KB} / \mathrm{CV}$ cells at $20 \mu \mathrm{M}$ (Fig. 2B). 
A

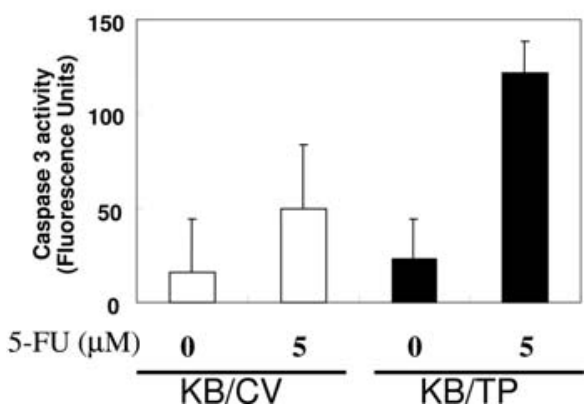

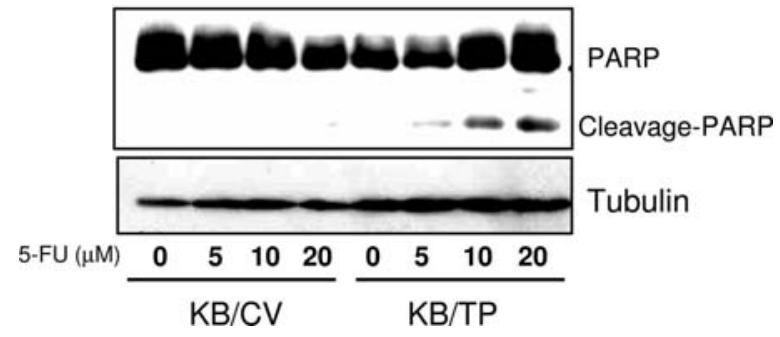

Figure 2. Activities of caspase 3 in $\mathrm{KB} / \mathrm{CV}$ and KB/TP cells treated with 5-FU. (A) Caspase 3 activity in cell lysates was measured using the specific substrates Ac-DEVD AMC for caspase 3. The effect of TP on the activity of caspase 3 in the cells treated with $5 \mu \mathrm{M} 5$-FU for $72 \mathrm{~h}$ was examined. Untreated cells were used as control. The data are expressed in arbitrary units. Bars, SD. (B) Induction of PARP cleavage product in KB/CV and KB/TP cells treated with 5-FU. KB/CV and KB/TP cells were incubated with 5-FU for $72 \mathrm{~h}$. Then total cell lysates (100 $\mu \mathrm{g}$ ) from the cells were separated by SDS-PAGE and transferred to a PVDF membrane. Protein levels in the cells were detected by immunoblot analysis using anti-PARP antibody.

A

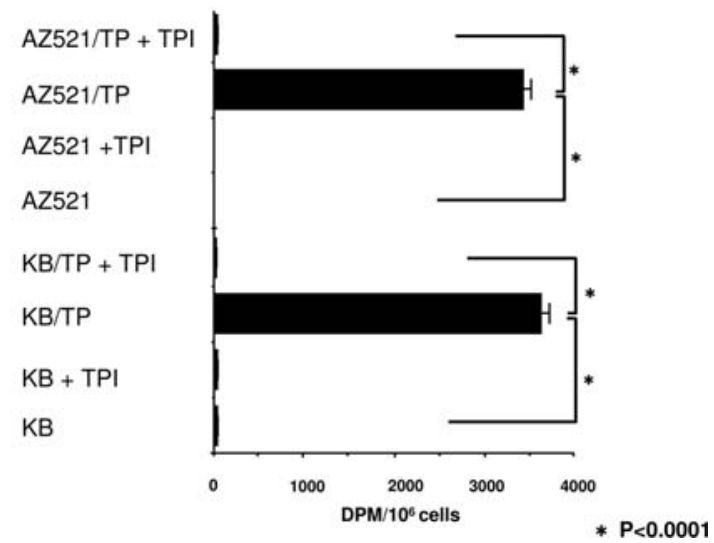

B

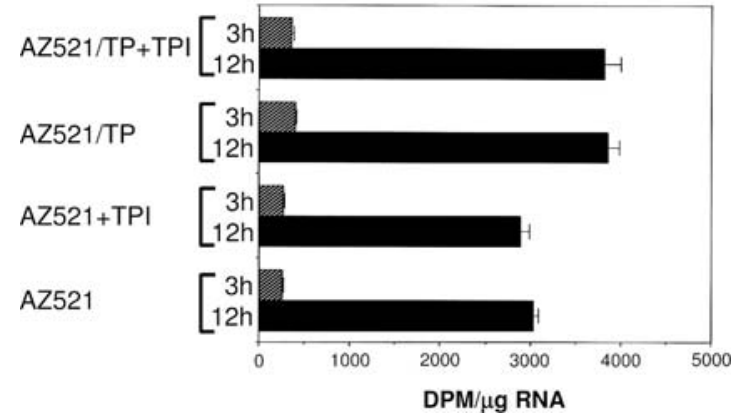

Figure 3. Intracellular FdUMP level in parental and TP expressing cells. (A) Each bar represents the mean \pm SE of three independent experiments. Statistical significance was determined by Student's t-test. ${ }^{*} \mathrm{P}<0.0001$. After cells were incubated with or without $100 \mu \mathrm{M}$ TPI overnight, the cells were exposed to $400 \mathrm{nM}$ $\left[{ }^{3} \mathrm{H}\right]-5-\mathrm{FU}$ for $3 \mathrm{~h}$. Intracellular FdUMP level was analysed by HPLC. (B) $\left[{ }^{3} \mathrm{H}\right]$ 5-FU level incorporated into RNA in parental and TP expressing cells. Each bar represents the mean $\pm \mathrm{SE}$ of three independent experiments.

Intracellular FdUMP level and incorporation of 5-FU in RNA. The amounts of FdUMP in AZ521/TP (3451.88 \pm 86.58$)$ and $\mathrm{KB} / \mathrm{TP}(3618.16 \pm 108.42)$ cells were significantly higher than those in AZ521 $(0.54 \pm 0.26)$ and KB $(43.58 \pm 6.10)$ cells. TPI decreased the FdUMP levels in AZ521/TP and KB/TP cells to the level close to those in their parental cells (Fig. 3A). We next examined 5-FU incorporation into RNA in AZ521 and AZ521/TP cells. As shown in Fig. 3B, TP did not affect the levels of $\left[{ }^{3} \mathrm{H}\right] 5-\mathrm{FU}$ incorporated into RNA.

Expression level of TS. AZ521, AZ521/TP, KB and KB/TP cells were exposed to $0.1 \mu \mathrm{M} 5$-FU without or with $10 \mu \mathrm{M}$ $\mathrm{LV}$ or $100 \mu \mathrm{M}$ TPI, then the expression level of TS and the ternary complex of TS, FdUMP and LV were examined by immunoblot analysis (Fig. 4). The expression level of TS in KB cells was higher than that of AZ521. The expression level of TS was increased by LV and 5-FU in AZ521 and AZ521/TP cells, respectively, but not in $\mathrm{KB}$ and $\mathrm{KB} / \mathrm{TP}$ cells. AZ521/TP and KB/TP cells treated with 5-FU without or with $\mathrm{LV}$ showed two bands, one at $36 \mathrm{kDa}$ representing free TS and the other at $38.5 \mathrm{kDa}$ representing the ternary complex. The level of the ternary complex in AZ521/TP cells treated with 5-FU in combination with LV was higher than in AZ521/TP cells treated with 5-FU alone. However, the level of the complex in $\mathrm{KB} / \mathrm{TP}$ cells treated with 5 -FU in combination with $\mathrm{LV}$ was comparable to that in $\mathrm{KB} / \mathrm{TP}$ cells treated with 5-FU alone. TPI suppressed the appearance of the ternary complex in the TP expressing cells treated with 5-FU.

The effect of 5-FU on the expression of Egr-1 and TSP-1 in $K B / T P$ cells. We previously reported that 5-FU up-regulated Egr-1 expression, resulting in the expression of antiangiogenic factor, TSP-1, in human colon carcinoma KM12C cells (23). Thus we investigated whether the induction of Egr-1 is augmented in $\mathrm{KB} / \mathrm{TP}$ cells compared with that in $\mathrm{KB} / \mathrm{CV}$ cells. 5-FU induced the expression of Egr-1 in KB/TP cells, but not in KB/CV cells (Fig. 5A). Egr-1 was induced by 5-FU augmented the promoter activity of TSP-1 and enhanced the transcription of TSP-1 gene (23). To examine whether the expression of TSP-1 is increased by $5-\mathrm{FU}$ in $\mathrm{KB} / \mathrm{TP}$ cells, we 
A

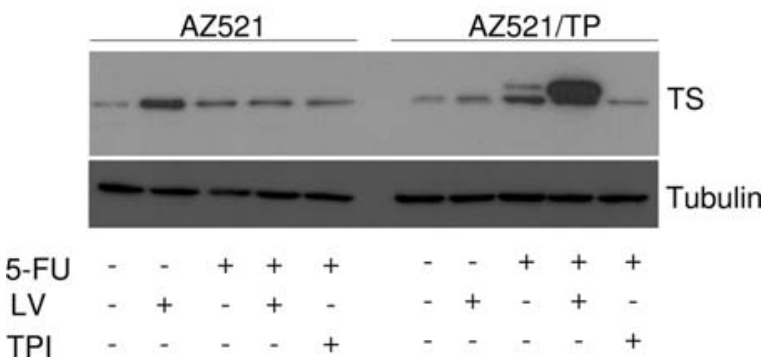

B

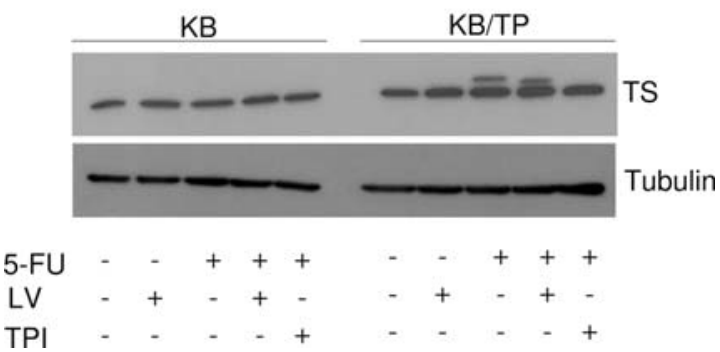

Figure 4. Expression of TS in KB, KB/TP, AZ521 and AZ521/TP cells. After $72 \mathrm{~h}$ treatment with $0.1 \mu \mathrm{M} 5$-FU in the presence and absence of $10 \mu \mathrm{M}$ LV or $100 \mu \mathrm{M}$ TPI, cells were lysed by freezing and thawing. Cell lysates were separated by SDS-PAGE and transferred to a PVDF membrane. TS levels in lysates were determined using a polyclonal antibody against TS.

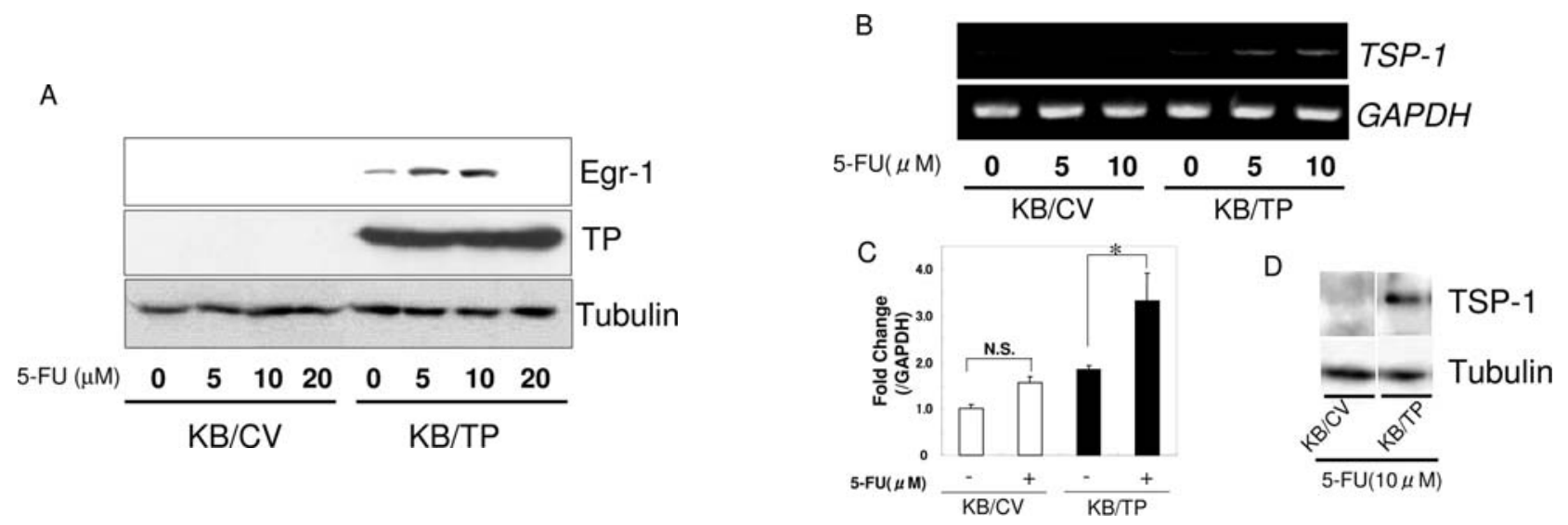

Figure 5. Effect of 5-FU on the expression of Egr-1 and TSP-1 in KB/CV and KB/TP cells. (A) Expression of Egr-1. Cells were treated with 5-FU at the indicated concentrations for $72 \mathrm{~h}$, and the levels of Egr-1 were determined by immunoblotting using an anti-Egr-1 antibody. (B) Expression of TSP-1 mRNA. Cells were treated with 5-FU at 5 and $10 \mu \mathrm{M}$ for $72 \mathrm{~h}$, and TSP-1 mRNA were detected using RT-PCR. (C) Quantification of relative TSP-1 mRNA levels. Cells were treated with 5-FU at $2 \mu \mathrm{M}$ for $72 \mathrm{~h}$ and TSP-1 mRNA was analyzed using quantitative real-time PCR. Bars, SD. *P<0.05. (D) Expression of TSP-1. Cells were treated with $10 \mu \mathrm{M} 5$-FU for $72 \mathrm{~h}$, then total cell lysates $(100 \mu \mathrm{g})$ from the cells were separated by SDS-PAGE and transferred to a PVDF membrane. Protein levels in the cells were detected by immunoblot analysis using an anti-TSP-1 antibody.

performed RT-PCR using specific primers for TSP-1 and immunoblot analysis using an antibody against TSP-1. When $\mathrm{KB} / \mathrm{TP}$ cells were treated with 5-FU, the expression levels of TSP-1 mRNA and TSP-1 protein were induced in KB/TP, but not in $\mathrm{KB} / \mathrm{CV}$ cells (Fig/ 5B-D).

The effect of LV and TPI on the induction of Egr-1 and TSP-1 by $5-F U$. We examined the expression of Egr-1 and TSP-1 in $\mathrm{KB} / \mathrm{TP}$ cells treated with $5-\mathrm{FU}$ in the presence or absence of LV. The Egr-1 level induced by 5-FU alone in $\mathrm{KB} / \mathrm{TP}$ cells was higher than that in $\mathrm{KB} / \mathrm{CV}$ cells. $\mathrm{LV}$ augmented the Egr-1 levels induced by 5-FU in both cell types. The expression of Egr-1 and TSP-1 mRNA in KB/TP cells treated with 5-FU in combination with LV was considerably higher than in $\mathrm{KB} / \mathrm{CV}$ cells treated with the same agents (Fig. 6A and B). Furthermore, TPI suppressed the expression of Egr-1 and TSP-1 mRNA in KB/TP cells treated with 5-FU (Fig. 6C and D).

\section{Discussion}

5-FU has been employed in the treatment of diverse neoplasitc diseases. 5-FU effectively inhibits both synthesis of thymi- dylate and function of RNA. Enzymatic conversion of 5-FU to the nucleotides FUTP and FdUMP, is required for 5-FU to exert its cytotoxic activity. Two routes are available for the formation of FdUMP. A reaction sequence involves reduction of the diphosphate nucleotide by ribonucleotide diphosphate reductase to the deoxynucleotide level and the eventual formation of FdUMP. 5-FU is also converted directly to fluorodeoxyuridine (5FUdR) by TP and further converted to FdUMP by thymidine kinase.

We found that TP increased the sensitivity of AZ521 and KB cells to 5-FU, and TPI abrogated this effect of TP. TPI almost completely suppressed the formation of FdUMP and consequently the ternary complex in TP-expressing AZ521 and KB cells. However, TPI could not inhibit the incorporation of $\left[{ }^{3} \mathrm{H}\right] 5-\mathrm{FU}$ into RNA in these cells. These results suggest that TP plays a pivotal role in the formation of FdUMP, but not of FUTP, in the TP-overexpressing cells. Transfection experiments have provided evidence that TP mediates the sensitivity of HT-29 and Colo320 human colon carcinoma cells to 5 -FU $(31,32)$. TP also increased the sensitivity of MCF-7 human breast cancer cells to 5'-deoxy5-fluorouridine (5'-DFUR), a prodrug of 5-FU (33). Furthermore, previous studies suggested that the level of TP activity 

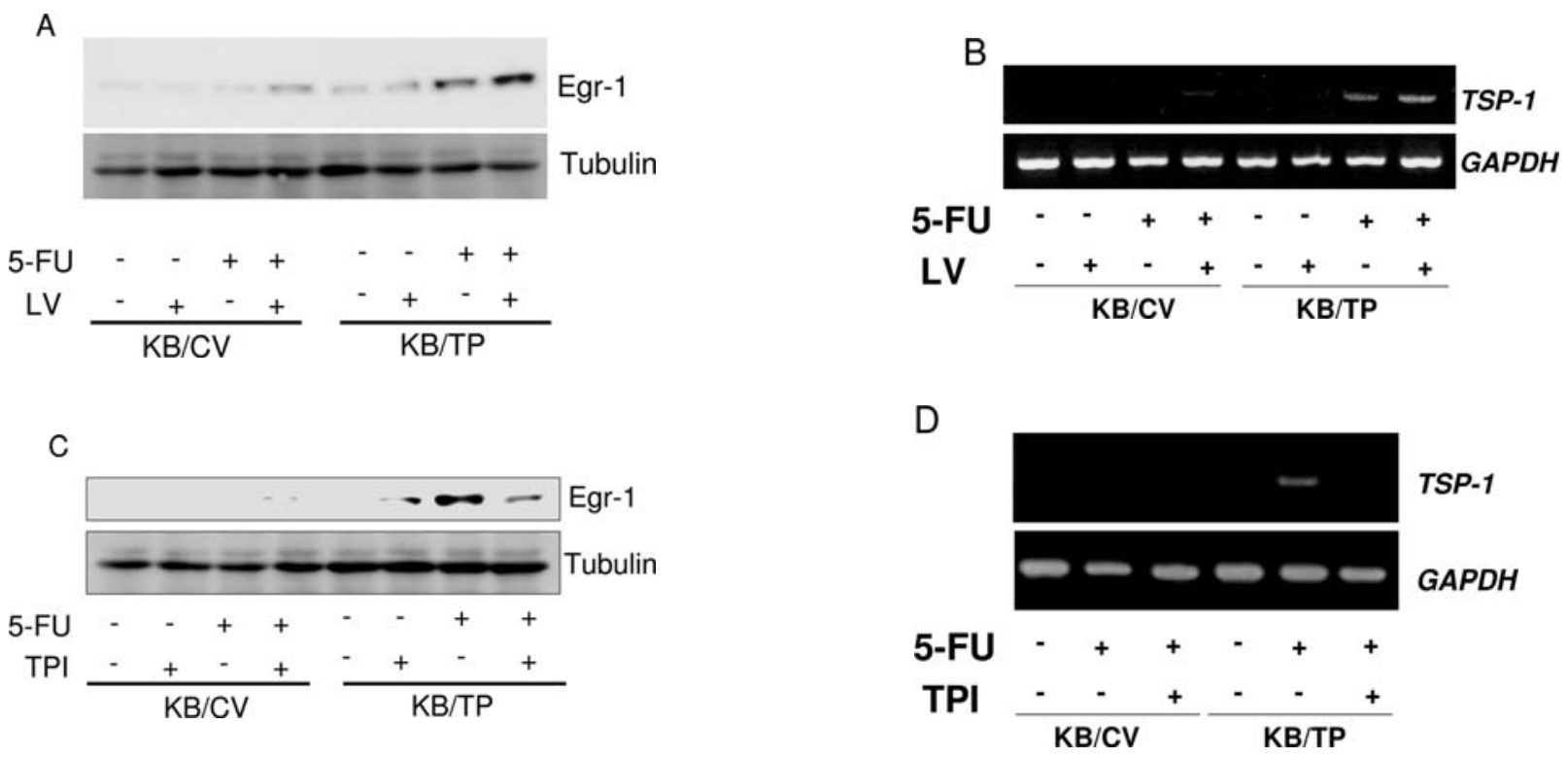

Figure 6. Effect of LV and TPI on the expression levels of Egr-1 and TSP-1 induced by 5-FU. (A) KB/CV and KB/TP cells were incubated with $10 \mu \mathrm{M} 5$-FU for $72 \mathrm{~h}$ in the absence or presence of $10 \mu \mathrm{M} \mathrm{LV}$. Total cell lysates (100 $\mu \mathrm{g}$ ) from the cells were separated by SDS-PAGE and transferred to a PVDF membrane. Protein levels in the cells were detected by immunoblot analysis using an anti-Egr-1 antibody. (B) KB/CV and KB/TP cells were incubated with $2 \mu \mathrm{M}$ 5 -FU for $72 \mathrm{~h}$ in the absence or presence of $10 \mu \mathrm{M} \mathrm{LV}$. TSP-1 mRNA was analyzed using RT-PCR. (C) KB/CV and KB/TP cells were incubated with $10 \mu \mathrm{M}$ 5-FU for $72 \mathrm{~h}$ in the absence or presence of $100 \mu \mathrm{M}$ TPI. Total cell lysates (100 $\mu \mathrm{g}$ ) from the cells were separated by SDS-PAGE and transferred to a PVDF membrane. Protein levels in the cells were detected by immunoblot analysis using an anti-Egr-1 antibody. (D) KB/CV and KB/TP cells were incubated with $5 \mu \mathrm{M}$ 5-FU for $48 \mathrm{~h}$ in the absence or presence of $100 \mu \mathrm{M}$ TPI. TSP-1 mRNA was analyzed using RT-PCR.

could be a predictive factor for the 5-FU cytotoxicity in vivo and in vitro (34-36). These studies are in accordance with our findings that the cytotoxicity of 5-FU was enhanced by TP expression in AZ521 human gastric carcinoma cells and KB.

Advances based on delineation of the mechanisms of action of 5-FU demonstrated that LV can potentiate the antitumor activity of 5-FU $(37,38)$. We showed that LV could potentiate the activity of 5-FU in TP-expressing AZ521/TP, but not in AZ521 cells. Expression of TP seems to be indispensable for the potentiating activity of LV. On the other hand, the sensitivity of $\mathrm{KB} / \mathrm{TP}$ cells to 5-FU was about 5-fold increased by $\mathrm{LV}$, but the difference in sensitivity was not significant. TS (EC 2.1.1.45), which converts deoxyuridine monophosphate (dUMP) to thymidylate, plays an essential role in the synthesis of DNA. Inhibition of TS by FdUMP is mediated by the formation of a stable ternary complex composed of FdUMP, TS, and the cofactor 5,10-methylenetetrahydrofolate $(21,22)$. The ternary complex was detected in both TP expressing cells, and the interaction of TS with FdUMP was enhanced by LV in AZ521/TP cells, but not in $\mathrm{KB} / \mathrm{TP}$ cells. This appears to be the reason why LV could not significantly increase the sensitivity to 5-FU of KB/TP cells. Further study is needed to elucidate why LV failed to augment the formation of the ternary complex. AZ521 cells were 93-fold more sensitive to 5-FU than KB cells. Some molecular bases for resistance to 5-FU have been identified. These mechanisms include amplification of TS and altered TS that is not inhibited by FdUMP $(39,40)$. The TS level was reported to be controlled by an autoregulatory feedback mechanism wherein the TS protein interact with and controls the translational efficiency of its own mRNA (41). Disruption of this autoregulatory loop by TS inhibitors leads to up-regulation of TS protein (42). Carcinoma cells might become rapidly resistant to the cytotoxic effect of 5-FU by this mechanism. These results suggest that the increased expression level of TS is one of the important mechanisms of 5-FU-resistance. The expression level of TS in AZ521 cells was considerably lower than that in KB cells. This difference in TS level might explain the difference in sensitivity to 5-FU between AZ521 and KB cells. Our findings showed that TP is crucially involved in the reaction sequence that convert 5-FU to FdUMP, that is the principal cytotoxic metabolite of 5-FU in the TP expressing cells. The level of TS and the stable ternary complex seem to be related to response to 5-FU in the TP-expressing cells.

Recently, we found that 5-FU induced TSP-1 in human colon carcinoma KM12C cells (23). A transcription factor, Egr-1, was also induced by 5-FU and bound to the promoter of TSP-1, enhancing its transcription and the subsequent production of TSP-1 protein. Moreover, we suggested that p38 mitogen-activated protein kinase (MAPK) plays an important role in 5-FU-induced EGR-1 transactivation. Egr-1 is a Cys2-His2 -typed zinc-finger transcription factor that has been implicated in the regulation of a number of genes involved in inflammation, differentiation, growth, and development (43). It also regulates the expression of a diverse array of genes involved in tumor metastasis, including TSP-1, plasminogen activator inhibitor (PAI-1), and transforming growth factor- $\beta 1$ (TGF- 31 ) $(44,45)$. TSP-1 is a potent inhibitor of neovascularization that limits tumor growth and induces apoptosis and growth inhibition in neovascular endothelial cells (46). Egr-1 possesses a strong inhibitory effect on the angiogenic activity of VEGF in vivo. High TSP-1 expression is also inversely correlated with invasive- 
ness and lymph node metastasis $(47,48)$. Although FUTP was expressed in $\mathrm{KB} / \mathrm{CV}$ at a level similar to that in $\mathrm{KB} / \mathrm{TP}$ cells, both Egr-1 and TSP-1 were only slightly detected in $\mathrm{KB} / \mathrm{CV}$ cells treated with 5-FU, if any. FUTP might not be implicated in the induction of Egr-1 and TSP-1 in KB/TP cells. Both Egr-1 and TSP-1 were detected in 5-FU-treated $\mathrm{KB} / \mathrm{TP}$ cells that involve considerable amount of FdUMP converted from 5-FU by TP. TPI inhibited the TP activity and attenuated the expression of Egr- 1 and TSP-1 mRNA, suggesting that TP activity is needed for the induction of Egr-1 and TSP-1 mRNA by 5-FU. On the other hand, LV that augmented the cytotoxic effect of FdUMP increased the expression of Egr-1 and TSP-1 mRNA. FdUMP blocks DNA synthesis and probably causes DNA strand bleakage. Cyclophosphamide, one of the alkylating agents, that seriously damages DNA molecule was previously reported to induce TSP-1 (49). These findings together with our previous findings (23) suggest that TP is needed for the induction of Egr-1 and TSP- 1 by $5-F U$ and the DNA damage by FdUMP caused the stress that activates p38 MAPK kinase pathway, and consequently induced Egr-1 and TSP-1 mRNA in the TPexpressing cells. Although further study is needed to elucidate whether Egr-1 and TSP-1 induction by 5-FU is implicated in the antitumor effect of 5-FU, our findings might be useful to develop new approaches for the treatment of TP-expressing tumors

\section{References}

1. Iltzsch MH, Kouni MH and Cha S: Kinetic studies of thymidine phosphorylase from mouse liver. Biochemistry 24: 6799-6807. 1985

2. Friedkin D and Roberts D: The enzymatic synthesis of nucleosides. J Biol Chem 207: 245-256, 1954.

3. Krenitsky TA, Koszalka GW and Tuttle JV: Purine nucleoside synthesis, an efficient method employing nucleoside phosphorylase. Biochemistry 20: 3615-3621, 1981

4. Zimmerman $M$ and Seidenberg J: Deoxyribosil transfer. Thymidine phosphorylase and nucleoside deoxyribosyltransferase in normal and malignant tissues. J Biol Chem 230: 2618-2621, 1964.

5. Gallo RC, Perry $S$ and Breitman TR: The enzymatic mechanisms for deoxythymidine synthesis in human leukocytes. J Biol Chem 242: 5059-5068, 1967.

6. Krenitsky TA: Pentosyl transfer mechanisms of the mammalian nucleoside phosphorylases. J Biol Chem 243: 2871-2875, 1968.

7. Takebayashi Y, Akiyama S, Akiba S, Yamada K, Miyadera K, Sumizawa T, Yamada Y, Murata F and Aikou T: Clinicopathologic and prognostic significance of an angiogenic factor, thymidine phosphorylase, in human colorectal carcinoma. J Natl Cancer Inst 88: 1110-1117, 1996

8. Imazono Y, Takebayashi Y, Nishiyama K, Akiba S, Miyadera K, Yamada Y, Akiyama S and Ohi Y: Correlation between thymidine phosphorylase expression and prognosis in human renal cell carcinoma. J Clin Oncol 15: 2570-2578, 1997.

9. Takebayashi Y, Yamada K, Miyadera K, Sumizawa T, Furukawa T, Kinoshita F, Aoki D, Okumura H, Yamada Y, Akiyama $\mathrm{S}$ and Aikou T: The activity and expression of thymidine phosphorylase in human solid tumors. Eur J Cancer 32 1227-1232, 1996.

10. Takebayashi Y, Miyadera K, Akiyama S, Hokita S, Yamada Y, Akiba S, Yamada Y, Sumizawa T and Aikou T: Expression of thymidine phosphorylase in human gastric carcinoma. Jpn J Cancer Res 87: 288-295, 1996.

11. Maeda K, Chung YS, Ogawa Y, Takatsuka S, Kang SM, Ogawa M, Sawada T, Onda N, Kato Y and Sowa M: Thymidine phosphorylase/platelet-derived endothelial cell growth factor expression associated with hepatic metastasis in gastric carcinoma. Br J Cancer 73: 884-888, 1996.
12. Koukourakis MI, Giatromanolaki A, O'Bryne KJ, Comley M, Whitehouse RM, Talbot DC, Gatter KC and Harris AL: Plateletderived endothelial cell growth factor expression correlates with tumor angiogenesis and prognosis in non-small cell lung cancer. Br J Cancer 75: 477-481, 1997.

13. Fox SB, Westwood M, Moghaddam A, Comley M, Turley H, Whitehouse RM, Bicknell R, Gatter KC and Harris AL: The angiogenic factor pletelet-derived endothelial cell growth factor/ thymidine phosphorylase is up-regulated in breast cancer epithelium and endothelium. Br J Cancer 73: 275-280, 1996.

14. Furukawa T, Yoshimura A, Sumizawa T, Haraguchi M, Akiyama S, Fukui K, Ishizawa $\mathrm{M}$ and Yamada Y: Angiogenic factor. Nature 356: 668, 1992.

15. Haraguchi M, Miyadera K, Uemura K, Sumizawa T, Furukawa T, Yamada K, Akiyama S and Yamada Y: Angiogenic activity of enzymes. Nature 368: 198, 1994.

16. Miyadera K, Sumizawa T, Haraguchi M, Yoshida H, Konstanty W Yamada Y and Akiyama S: Role of thymidine phosphorylase activity in the angiogenic effect of platelet derived endothelial cell growth factor/thymidine phosphorylase. Cancer Res 55: 1687-1690, 1995

17. Piper AA and Fox RM: Biochemical basis for the differential sensitivity of human T-and B-lymphocyte lines to 5-fluorouracil. Cancer Res 42: 3753-3760, 1982.

18. Miw M, Cook A and Ishitsuka H: Enzymatic cleavage of various fluorinated pyrimidine nucleosides to 5-fluorouracil and their antiproliferative activities in human and murine tumor cells. Chem Pharm Bull 34: 4225-4232, 1986.

19. Verez Z, Szabolcs A, Szinai I, Denes G and Jeney A: Enzymatic cleavage of 5-substituted-2'-deoxyuridines by pyrimidine nucleoside phosphorylases. Biochem Pharmacol 35: 1057-1059, 1986.

20. Heidelberger C, Chaudhuri NK, Danenberg P, Mooren D, Griesbach L, Duschinsky R, Schnitzer RJ, Pleven E and Scheiner J: Fluorinated pyrimidines, a new class of tumourinhibitory compounds. Nature 179: 663-666, 1957.

21. Santi DV, McHenry CS and Sommer H: Mechanism of intraction of thymidylate synthase with 5-fluorouracil. Biochemistry 13: 471-481, 1974

22. Danenberg PV and Lockshin A: Fluorinated pyrimidines as tight-binding inhibitors of thymidylate synthase. Pharmacol Ther 13: 69-90, 1981.

23. Zhao HY, Ooyama A, Yamamoto M, Ikeda R, Haraguchi M, Tabata S, Furukawa T, Che XF, Zhang S, Oka T, Fukushima M, Nakagawa M, Ono M, Kuwano M and Akiyama S: Molecular basis for the induction of an angiogenesis inhibitor, thrombospondin-1, by 5-fluorouracil. Cancer Res 68: 7035-7041, 2008.

24. Potter H, Weir L and Leder P: Enhancer-dependent expression of human $\mathrm{k}$ immunoglobulin genes introduced into mouse pre-B lymphocytes by electroporation. Proc Natl Acad Sci USA 81: 7161-7165, 1984

25. Yoshimura A, Kuwazuru Y, Furukawa T, Yoshida H, Yamada K and Akiyama S: Purification and tissue distribution of human thymidine phosphorylase; high expression in lymphocytes, reticulocytes and tumors. Biochim Biophys Acta 1034: 107-113, 1990.

26. Bradford MM: A rapid and sensitive method for the quantitation of microgram quantities of protein utilizing the principle of protein-dye binding. Anal Biochem 72: 248-254, 1976.

27. Laemmli UK: Cleavage of structural proteins during the assembly of the head of bacteriophage T4. Nature 227: 680-685, 1970.

28. Andersen JK: Electroblotting of multiple gels: a simple apparatus without buffer tank for rapid transfer of proteins from polyacrylamide to nitrocellulose. J Biochem Biophys Methods 10: 203-209, 1984.

29. Carmichael J, DeGraff WG, Gazder AF, Minna JD and Mitchell JB: Evaluation of a tetrazolium-based semiautomated colorimetric Assay: assesment of chemosensitivity testing. Cancer Res 47: 936-942, 1987.

30. Inaba M, Mitsuhashi J, Sawada H, Miike N, Naoe Y, Daimon A, Koizumi K, Tsujimoto H and Fukushima M: Reduced activity of anabolizing enzymes in 5-fluorouracil resistant human stomach cancer cells. Jpn J Cancer Res 87: 212-220, 1996.

31. Schwartz EL, Baptiste N, Wadler S and Makower D: Thymidine phosphorylase madiates the sensitivity of human colon carcinoma cells to 5-fluorouracil. J Biol Chem 270: 19073-19077, 1985.

32. Temmink OH, de Bruin M, Turksma AW, Cricca S, Laan AC and Peters GJ: Activity and substrate specificity of pyrimidine phosphorylases and their role in fluoropyrimidine sensitivity in colon cancer cell lines. Int J Biochem Cell Biol 39: 565-575, 2007. 
33. Patterson AV, Zhang H, Moghaddam A, Bicknell R, Talbot DC, Straford IJ and Harris AL: Increased sensitivity to the prodrug to 5'-deoxy-5-fluorouridine and modulation of 5-fluoro-2'deoxyuridine sensitivity in MCF-7 cells transfected with thymidine phosphorylase. Br J Cancer 72: 669-675, 1995.

34. Fox SB, Engels K, Comley M, Whitehouse RM, Turley H, Gatter KC and Harris AL: Relationship of elevated tumour thymidine phosphorylase in node-positive breast carcinomas to the effects of adjuvant CMF. Ann Oncol 8: 271-275, 1997.

35. Griffiths L and Stratford IJ: Pletelet derived endothelial cell growth factor thymidine phosphorylase in tumour growth and responce to therapy. Br J Cancer 76: 689-693, 1997.

36. Mader RM, Sieder AE, Braun J, Rizovski B, Kalipciyan M, Mueller MW, Jakesz R, Rainer H and Steger GG: Transcription and activity of 5-fluorouracil converting enzymes in fluoropyrimidines resistance in colon cancer in vitro. Biochem Pharmacol 54: 1233-1242, 1997.

37. Piedbois P, Buyse M and Rustum Y: Modulation of fluorouracil by leucovorin in patients with advanced colorectal cancer. J Clin Oncol 10: 896-903, 1992.

38. Mansoni S: Efficacy of adjuvant fluorouracil and folinic acid in colon cancer. Lancet 345: 939-949, 1995.

39. Washtien WL: Thymidylate synthetase levels as a factor in 5fluorodeoxyuridine and methotrexate cytotoxicity in gastrointestinal tumor cells. Mol Pharmacol 21: 723-728, 1982.

40. Barbour KW, Berger SH and Berger FG: Single amino acid substitution delines a naturally occurring genetic variant of human thymidylate synthase. Mol Pharmacol 37: 515-518, 1990.

41. Tai N, Schmitz JC, Liu J, Lin X, Bailly M, Chen TM and Chu E: Translational autoregulation of thymidylate synthase and dihydrofolate reductase. Front Biosci 9: 2521-2526, 2004.
42. Welsh SJ, Titley J, Brunton L, Valenti M, Monaghan P, Jackman AL and Aherne GW: Comparison of thymidylate synthase (TS) protein up-regulation after exposure to TS inhibitors in normal and tumor cell lines and tissues. Clin Cancer Res 6: 2538-2546, 2000.

43. Baek SJ, Kim JS, Moore SM, Lee SH, Martinez J and Eling TE: Cyclooxygenase inhibitors induce the expression of the tumor suppressor gene EGR-1, which results in the up-regulation of NAG-1, an antitumorigenic protein. Mol Pharmacol 67: 356-364, 2005.

44. Shingu T and Bornstein P: Overlapping Egr-1 and Sp1 sites function in the regulation of transcription of the mouse thrombospondin 1 gene. J Biol Chem 269: 32551-32557, 1994.

45. Liu C, Yao J, Mercola D and Adamson E: The transcription factor EGR-1 directly transactivates the fibronectin gene and enhances attachment of human glioblastoma cell line U251. J Biol Chem 275: 20315-20323, 2000.

46. Jiménez B, Volpert OV, Crawford SE, Febbraio M, Silverstein RL and Bouck N: Signals leading to apoptosis-dependent inhibition of neovascularization by thrombospondin-1. Nat Med 6: 41-48, 2000.

47. Lawler J: Thrombospondin-1 as an endogenous inhibitor of angiogenesis and tumor growth. J Cell Mol Med 6: 1-12, 2002.

48. Yao L, Zhao YL, Itoh S, Wada S, Yue L and Furuta I: Thrombospondin-1 expression in oral squamous cell carcinomas: correlations with tumor vascularity, clinicopathological features and survival. Oral Oncol 36: 539-544, 2000.

49. Bocci G, Francia G, Man S, Lawler J and Kerbel RS: Thrombospondin 1, a mediator of the antiangiogenic effects of lowdose metronomic chemotherapy. Proc Natl Acad Sci USA 100: 12917-12922, 2003. 